\title{
Contamination of water resources by pathogenic bacteria
}

\author{
Pramod K Pandey ${ }^{1 *}$, Philip H Kass ${ }^{1}$, Michelle L Soupir ${ }^{2}$, Sagor Biswas ${ }^{1}$ and Vijay P Singh ${ }^{3}$
}

\begin{abstract}
Water-borne pathogen contamination in water resources and related diseases are a major water quality concern throughout the world. Increasing interest in controlling water-borne pathogens in water resources evidenced by a large number of recent publications clearly attests to the need for studies that synthesize knowledge from multiple fields covering comparative aspects of pathogen contamination, and unify them in a single place in order to present and address the problem as a whole. Providing a broader perceptive of pathogen contamination in freshwater (rivers, lakes, reservoirs, groundwater) and saline water (estuaries and coastal waters) resources, this review paper attempts to develop the first comprehensive single source of existing information on pathogen contamination in multiple types of water resources. In addition, a comprehensive discussion describes the challenges associated with using indicator organisms. Potential impacts of water resources development on pathogen contamination as well as challenges that lie ahead for addressing pathogen contamination are also discussed.
\end{abstract}

Keywords: Pathogens; Contamination; Water resources; Watershed; Pathogens transport

\section{Introduction}

Water-borne pathogen contamination in ambient water bodies and related diseases are a major water quality concern throughout the world. Pathogen contamination is a serious issue for almost all types of ambient water bodies, making its recognition and understanding essential (U.S. EPA 2012a). The United Nations identified improving water quality as one of the eight Millennium Development Goals (MDGs). Its target is to reduce the number of people without access to safe water by $50 \%$ by 2015 (WHO 2011). Because of the overwhelming scientific evidence for climate change (IPCC 2007), it is also important to understand how perturbations in weather patterns can potentially impact pathogen levels in water resources. To meet future demands of water for food, energy, and ecosystems, increasing water storage structures (i.e., dams) must be a component of long-range planning (World Bank 2010). However, such new structures can potentially degrade water quality and exacerbate public health risk.

\footnotetext{
* Correspondence: pkpandey@ucdavis.edu

${ }^{1}$ Department of Population Health and Reproduction, University of California, Davis, California, USA

Full list of author information is available at the end of the article
}

While several review papers are currently available (Bradford et al. 2013; Pachepsky and Shelton 2011; Pang 2009; Jin and Flury 2002; John and Rose 2005; Jamieson et al. 2004; Jamieson et al. 2002; Arnone and Walling 2007; Kay et al. 2007), there is a manifest need for additional transdisciplinary studies that assimilate knowledge gained from multi-research endeavors studying pathogen contamination, and provide a comprehensive synopsis in order to comprehend the entirety of the problem. Therefore, the goal of this review is to present a broad research scope assessment of pathogen contamination of water resources and the associated challenges it presents. We synthesize the potential health risks imposed by pathogens in water resources by providing existing knowledge that covers surface water, groundwater, fresh water, and saline water. Further, the impact of water resources development on pathogen contamination, future challenges, and recommendations are summarized. In addition, we provide a brief discussion describing water-borne pathogen footprints and potential challenges associated with the use of indicator organisms for assessing water quality.

\section{Health risk}

Water-borne diseases (i.e., diarrhea, gastrointestinal illness) caused by various bacteria, viruses, and protozoa have been

\section{实}


the causes of many outbreaks (Craun et al. 2006). In developing countries, such as those in Africa, water-borne diseases infect millions (Fenwick 2006). According to World Health Organization (WHO), each year 3.4 million people, mostly children, die from water-related diseases (WHO 2014). According to United Nations Children's Fund (UNICEF) assessment, 4000 children die each day as a result of contaminated water (UNICEF 2014). WHO (2010) reports that over 2.6 billion people lack access to clean water, which is responsible for about 2.2 million deaths annually, of which 1.4 million are in children. Improving water quality can reduce the global disease burden by approximately $4 \%$ (WHO 2010).

Although water-associated diseases in developing countries are prevalent, they are also a serious challenge in developed countries. A study by Arnone and Walling (2007), who compiled data of outbreaks in the U.S. (1986 - 2000), reported 5,905 cases and 95 outbreaks associated with recreational water. Gastrointestinal Illness (GI) caused by variety of different microbes and germs, which causes symptoms, such as diarrhea, nausea, vomiting, fever, abdominal pain, was responsible for about $29.53 \%$ cases. More than $27 \%$ of cases were caused by Shigella spp. In addition, 10.99\%, 10.08\%, and $6.59 \%$ of the cases were caused by Cryptosporidium parvum, Adenovirus 3, and Leptospira, respectively. Nearly $23 \%$ and $21 \%$ of the outbreaks were caused by GI and Shigella spp, respectively. In addition, 16.84\%, $12.63 \%$, and $7.37 \%$ of the outbreaks were caused by Naegleria fowleri, E. coli 0157:H7, and Schistosoma spp., respectively. Besides acute gastroenteritis, major etiological agents such as Giarida, Cryptosporadium, E. coli 0157:H7, V. cholera, and Salmonella were the agents responsible for many outbreaks (Craun et al. 2006). During the same period 437,082 cases and 48 outbreaks were caused by contaminated drinking water, of which about 95.89\% of the cases were caused by Cryptosporidium parvum. Nearly $42 \%$ and $31 \%$ of the outbreaks were caused by Giardia lamblia and GI, respectively. Reporting statistics on water-borne outbreaks in the U.S., Craun et al. (2006) found that at least 1870 outbreaks (23 per year) occurred between 1920 and 2002. These reported outbreaks and their reported incidence of illnesses are likely to be an underestimation of actual numbers because of nonreported cases and missing exposure information. To protect public health, the U.S. EPA's National Primary Drinking Water Regulations (NPDWRs) contain standards describing the Maximum Contaminant Level (MCL) - the highest level of a contaminate allowable in drinking water. The U.S. EPA has defined the MCL of various microorganisms, such as Cryptosporidium, Giardia lamblia, Legionella, and Total Coliforms (including fecal coliform and E. coli), and viruses (U.S. EPA 2012b). The Maximum Contaminant Level Goal (MCLG) - the level of a contaminant in drinking water below which there is no known risk to public health, has also been proposed by the U.S. EPA. The MCLC levels for Cryptosporidium, Giardia lamblia, Legionella, and Total Coliforms are zero. The EPA requires 99\% removal of Cryptosporidium in drinking water, and the removal percentages of Giardia lamblia and viruses are 99.9 and $99.99 \%$, respectively. Although there is no limit for Legionella, EPA believes that if Giardia lamblia and viruses are removed/inactivated, then drinking water likely to be free of Legionella. The U.S. EPA requires routine sampling of drinking water for testing total coliform and E. coli, and if a routine sample is positive, then repeat samples are required. If, in any repeat sample, total coliform or E. coli is detected then the drinking water has an acute MCL violation. For a drinking water system that collects fewer than 40 routine samples per month, no more than one sample can be total coliform-positive per month. For a system that collects more than 40 routine samples, no more than $5 \%$ of samples total coliform-positive in a month is allowed (U.S. EPA 2012b).

Each year approximately 42,000 cases of salmonellosis are reported in the U.S. (CDC 2014). Schistosomiasis is not reported in the U.S. because it is not endemic; however, 200 million people are infected worldwide. In 2011, about 1,060 cases of Guinea worm disease, caused by the parasite Dracunculus medinensis, were reported in many remote parts of Africa that do not have safe drinking water. Malaria, a protozoal disease of the Genus Plasmodium transmitted by mosquitos breeding in contaminated water, affects 300-500 million people, and causes over one million deaths each year (more than $90 \%$ of deaths in Africa). Overall the morbidity and mortality caused by contaminated water are enormous and need to be controlled by improving the security of safe water (i.e., recreational as well as drinking water) in both developing and developed countries.

\section{Historical perspective of water-borne diseases}

Water contamination has a long presence in human history, with descriptions in the Sushruta Samshita about water-borne diseases resembling cholera in an Indian text written in Sanskrit as early as 500-400 B.C. (Colwell 1996). Although cholera infections have not been reported in recent years in developed countries mainly due to improved sanitation, millions of people each year continue to get infected by Vibrio cholera in developing countries (Nelson et al. 2009). The World Health Organization reports about 3-5 million cholera cases and 10,000 - 120,000 deaths, mainly in developing countries, due to cholera every year. Over time, cholera has caused millions of deaths in developing as well as developed countries (Colwell 1996; Okun 1996). For instance, a major outbreak of cholera was reported in 
London in 1849. Dr. John Snow, a physician to Queen Victoria, showed a relationship between people infected by cholera and contaminated water (Snow 1854; Colwell 1996). Jordan et al. (1904), Ruediger (1911), Simons et al. (1922), and Rudolfs et al. (1950) provide excellent reviews on incidents during the early 19th century. Colwell (1996) reported that in the mid and late 18th century, cholera infected millions of people all over the world. The worst outbreak in recent memory occurred in Haiti following the devastating earthquake affecting the capital and surrounding regions, with almost a half a million cases, killing thousands of people (CDC 2011).

\section{Water-borne pathogen footprints and challenges}

Indicator organisms are commonly used to assess the levels of pathogens in water resources; i.e., water-borne pathogen footprints of water resources. Monitoring the levels of indicator organisms (such as fecal coliforms, E. coli) (Figure 1) is a common approach for quantifying the potential pathogen loads in ambient water bodies. For decades, public health officials/scientists have evaluated water quality by enumerating fecal coliforms and $E$. coli levels in rivers, lakes, estuaries, and coastal waters (Malakoff 2002; Pandey et al. 2012a; Pandey et al. 2012b; Pandey and Soupir 2013). There is, however, much debate regarding current indicator organisms and their ability to represent the potential presence of pathogenic bacteria. In addition, identifying the source of pathogens (e.g., human waste, animal waste, wildlife excreta, and waterfowl droppings) (Figure 2) is challenging (Malakoff 2002; Dickerson et al. 2007). There is potential to use a relatively new approach such as microbial source tracking (MST) to trace the origin of fecal coliform (Scott et al. 2002; Grave et al. 2007; Dickerson et al. 2007; Ibekwe et al. 2011; Ma et al. 2014). In the past, the MST method was exploited by antibiotic resistance analysis to assess the impact of cattle on water quality on a watershed scale (Grave et al. 2007). The authors suggested that host-origin libraries, based on a phenotypic method, are useful for tracking the pathogen sources. Many MST methods, however, rely on the assumption that some strains of bacteria are found only within a single kind or group of animals. This assumption can be debatable when it comes to the common fecal bacteria E. coli (Malakoff 2002). Therefore, caution is needed while using E. coli for source tracking (Gordon 2001). Further, the cost to develop libraries, implement extensive sampling programs needed for verifying the MST method, and calculate uncertainties associated with the method are legitimate issues, which requires attention before exploiting the MST method at watershed scale.

Currently, public health officials/scientists rely on exposure limits for assessing pathogen levels in water resources, which have been established to protect human

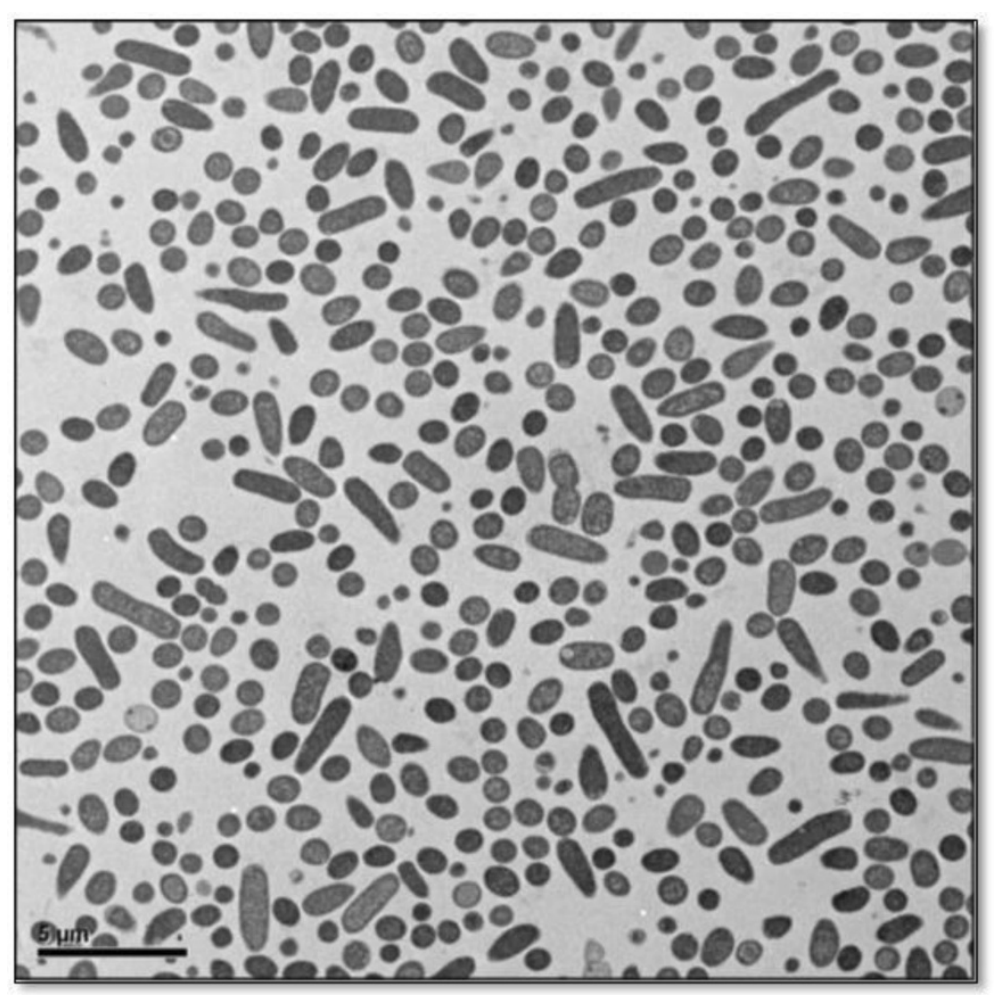

Figure 1 Transmission electron micrograph of E. coli (0157:H7; ATCC: 35150). 


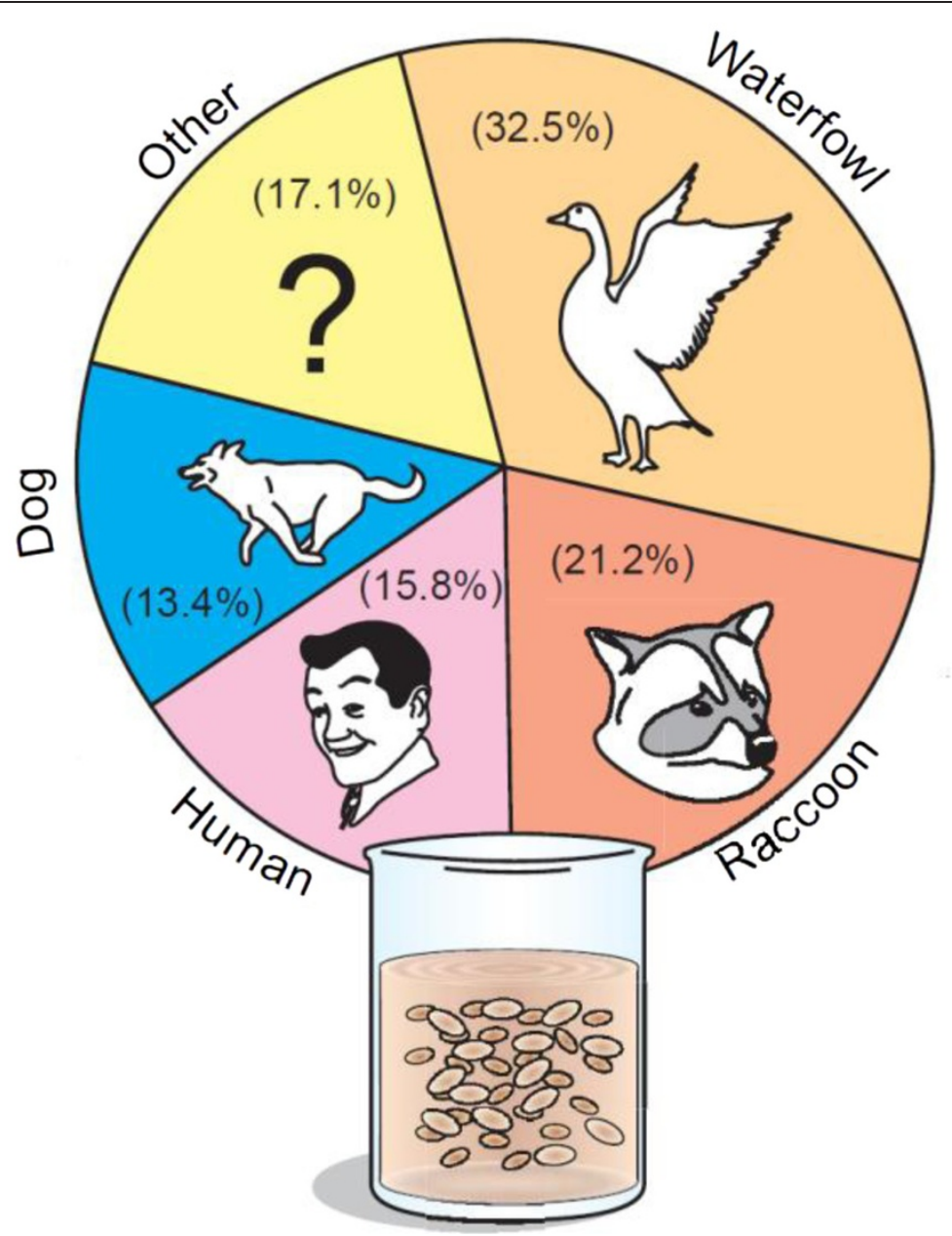

Figure 2 Challenges in identifying enteric pathogen sources (source: Malakoff, 2002).

health. The EPA defines acceptable recreational limits as those that will result in eight or fewer swimming-related gastrointestinal (GI) illnesses out of every 1,000 swimmers (U.S. EPA 1986). The current U.S. EPA fresh water quality criteria for $E$. coli is a geometric mean not exceeding $126 \mathrm{CFU} / 100 \mathrm{ml}$, or no samples exceeding a single sample maximum of 235 CFU/100 ml (U.S. EPA 2001). Criteria were developed based on the U.S. EPA measurements of total and Highly Credible Gastrointestinal Illnesses (HCGI), which correlated with E. coli densities $(\mathrm{r}=0.804)$ in fresh recreational waters (Dufour 1984). Multiple studies have identified trends between indicator organisms in water and GI illness in humans, including vomiting, diarrhea, and fever (Cabelli 1983; Wade et al. 2006). Recent work by Edge et al. (2010) detected water-borne E. coli in $80 \%$ of water samples with $E$. coli levels of less than $100 \mathrm{CFU} / 100 \mathrm{ml}$. Another study by Wade et al. (2006) reported significant positive trends between increased GI illness and indicator organisms at the Lake Michigan beach, and a positive trend with indicators such as $E$. coli at a Lake Erie beach. Recently, the use of indicator organisms (e.g., fecal coliforms, E. coli) for assessing pathogen levels has been debated more often than ever; however, the use of indicator organisms is likely to continue for assessing pathogen levels in water resources potentially because of the lack of an alternative reliable solution.

\section{Pathogen contamination in water resources}

The U.S. EPA, which monitors water quality of various ambient water bodies, estimated that pathogens impair more than 480,000 $\mathrm{km}$ of rivers and shorelines and 2 million ha of lakes in the U.S. (U.S. Environmental Protection Agency 2010a). According to EPA estimates, pathogens are the leading cause of impairment for 303 (d) listed waters (i.e., list of impaired and threatened waters that the Clean Water Act requires all states to submit for EPA approval) (Figure 3) (U.S. EPA 2014a, 2014b, 2014c). A total of 71,917 causes of impairment have been reported, and the top five causes of impairment are shown in Figure 3. Pathogen contamination clearly dominates the causes of impairment (U.S. EPA 2014a, 2014b, 2014c). 


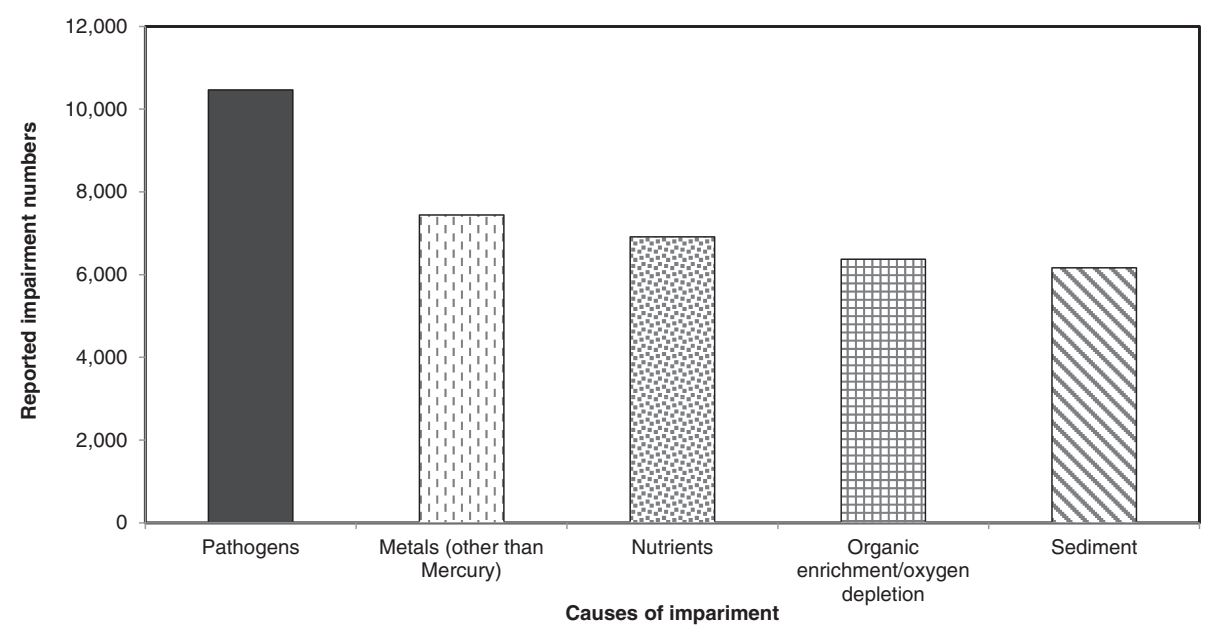

Figure 3 Causes of impairment in the U.S. (data source: U.S. EPA (2014a, 2014b, 2014c)).

Studies by Diffey (1991), Brookes et al. (2004), Jamieson et al. (2004), Gerba and Smith (2005), Gerba and McLeod (1976), Hipsey et al. (2008), Pachepsky and Shelton (2011) reviewed the current studies of water-borne pathogen transport, with particular reference to freshwater and estuarine sediments. In addition, many current reviews focus on specific aspects of water resources, for instance, John and Rose (2005) focused on groundwater, Brookes et al. (2004) focused on reservoirs and lakes, Jamieson et al. (2004) focused on agricultural watersheds, and Kay et al. (2007) reviewed catchment microbial dynamics. The review study presented here uses a relatively broader approach for understanding how water-borne pathogens can potentially impact public health and various ambient water bodies. In addition, existing challenges, while assessing pathogen levels in water resources are discussed.

\section{Coastal and estuarine environments}

In the U.S., elevated pathogen levels are a leading cause of impairments of coastal environments (U.S. EPA 2014a, 2014b, 2014c). Urban runoff and sewers have been identified as the primary source of coastal water impairments. Rippey (1994) reported about 400 outbreaks and 14,000 cases caused by pathogen contaminated coastal water since the late 1800 s in the U.S. Impairments of coastal environments have major economic impacts on the U.S. For example, losses caused by pathogen contamination in Massachusetts are more than $\$ 75$ million each year (Weiskel et al. 1996). The studies, which elaborate various pathogens in coastal environment and their survival mechanism, are summarized in Table 1.

The sources of coastal water contamination are: point discharges of treated and untreated sewage from shoreline outfalls, and non-point discharges. The non-point sources, such as runoff from naturally vegetated areas, discharge pathogens into coastal waters. Besides runoff from vegetated areas, the storm water runoff from urban, commercial, and industrial lands also discharges pathogens into coastal waters. In addition, other sources, such as malfunctioning or poorly sited septic systems, can also introduce significant amounts of pathogens (Sayler et al. 1975; Howe et al. 2002). Weiskel et al. (1996) reported that direct deposition of waterfowl feces was a considerable source of pathogens. Fayer and Trout (2005) summarized the transport of various pathogens, such as Giardia, Toxoplasma, and Cryptosporidium (zoonotic parasites) in the coastal environment. Moreover, the presence of sediment in seawater can also increase the survival chance of fecal coliforms, such as E. coli (Gerba nd McLeod 1976; Goyal et al. 1977). Solo-Gabriele et al. (2000) showed that the location and timing of storms of the coastal area in tropical and subtropical environments are also important factors that can potentially influence coastal water quality.

Previous studies have shown that the direct discharge of storm water runoff into coastal waters through storm drain systems can cause pathogen contamination, even where separate storm and sanitary sewer systems are in place. For instance, Weiskel et al. (1996) found that about $16 \%$ of the total fecal coliform inputs were caused by storm water entering Buttermilk Bay in Massachusetts. In addition, coastal rivers draining largely undeveloped watersheds with extensive riparian wetlands can be a natural source of fecal pathogens to coastal waters (Viau et al. 2011; Staley et al. 2014; Roberts et al. 2013; Liang et al. 2013; Wilkes et al. 2014). On-site septic systems can also contribute significant amounts of fecal pathogens to coastal waters in low-lying finegrained geological settings where saturated soils enhance pathogen growth. Weiskel et al. (1996) reported that shoreline wrack deposits could act as a reservoir 
Table 1 Studies describing pathogen contamination in saline water (coastal and estuary environments)

\begin{tabular}{|c|c|c|c|}
\hline Author(s) year & Organisms & Results & Study remarks \\
\hline \multicolumn{4}{|l|}{ Coastal water } \\
\hline Gerba and McLeod (1976) & E. coli, fecal coliform & $\begin{array}{l}\text { Longer survival in the sediment } \\
\text { presence in seawater }\end{array}$ & $\begin{array}{l}\text { Sediment influence on pathogen } \\
\text { survival }\end{array}$ \\
\hline Goyal et al. (1977) & Total coliform, fecal coliform & $\begin{array}{l}\text { Sediments of shallow canal can } \\
\text { act as a reservoir }\end{array}$ & $\begin{array}{l}\text { Pathogens distribution in water } \\
\text { and sediment }\end{array}$ \\
\hline Kapuscinski and Mitchell (1983) & E. coli, bacteriophages & $\begin{array}{l}\text { E. coli survives longer than } \\
\text { bacteriophages }\end{array}$ & Survival of pathogens in sunlight \\
\hline Rao et al. (1984) & Enteroviruses (Polio and Rota) & $\begin{array}{l}\text { Abundance viruses were attached } \\
\text { with sediment }\end{array}$ & $\begin{array}{l}\text { Viruses distribution in water and } \\
\text { sediment }\end{array}$ \\
\hline Weiskel et al. (1996) & Fecal coliform & $\begin{array}{l}\text { Waterfowl major source of fecal } \\
\text { coliform inputs }\end{array}$ & $\begin{array}{l}\text { Pathogen source and transport } \\
\text { pathways }\end{array}$ \\
\hline Sinton et al. (1999) & Bacteria and Fecal bacteriophages & $\begin{array}{l}\text { Somatic coliphages shown } \\
\text { prolonged survival }\end{array}$ & $\begin{array}{l}\text { Sunlight influence on sewage-polluted } \\
\text { seawater }\end{array}$ \\
\hline Solo-Gabriele et al. (2000) & E. coli & $\begin{array}{l}\text { Riverbanks as the primary } \\
\text { pathogen source }\end{array}$ & $\begin{array}{l}\text { Sources of pathogens on subtropical } \\
\text { environment }\end{array}$ \\
\hline Nasser et al. (2003) & Cryptosporidium, viruses, E. coli & $\begin{array}{l}\text { E. coli die-off was faster than } \\
\text { other pathogens }\end{array}$ & $\begin{array}{l}\text { Comparative survival of various } \\
\text { pathogens }\end{array}$ \\
\hline Schriewer et al. (2010) & $\begin{array}{l}\text { Bacteroidales, fecal indicator, } \\
\text { protozoa, bacteria }\end{array}$ & $\begin{array}{l}\text { Bacteroidales have shown higher } \\
\text { predictive skill than fecal indicators }\end{array}$ & $\begin{array}{l}\text { Bacteroidales as a predictor of } \\
\text { pathogens in coastal water }\end{array}$ \\
\hline \multicolumn{4}{|l|}{ Estuaries } \\
\hline Ketchum et al. (1952) & Coliform, zooplankton & $\begin{array}{l}\text { Sactericidal and predation } \\
\text { caused coliform die-off }\end{array}$ & $\begin{array}{l}\text { Processes responsible for pathogens } \\
\text { decrease }\end{array}$ \\
\hline Smith et al. (1978) & Echovirus 1, coxsackieviruses & $\begin{array}{l}\text { Sediment prolonged viruses } \\
\text { survival }\end{array}$ & Persistence of pathogen viruses \\
\hline Rhodes and Kator (1990) & E. coli & Mortality rises in sunlight & $\begin{array}{l}\text { Indigenous microbiota and sunlight } \\
\text { influence }\end{array}$ \\
\hline White et al. (1998) & Perkinsus marinus & $\begin{array}{l}\text { Use of Kriging analysis for } \\
\text { disease prevalence }\end{array}$ & $\begin{array}{l}\text { Use of GIS in pathogen distribution } \\
\text { analysis }\end{array}$ \\
\hline Lipp et al. (2001) & Vibrio vulnificus & $\begin{array}{l}\text { Salinity controls the distribution } \\
\text { of pathogens }\end{array}$ & Distribution of human pathogens \\
\hline Desmarais et al. (2002) & E. coli, C. perfringens & $\begin{array}{l}\text { Pathogens re-grown with tides } \\
\text { and sterile sediment }\end{array}$ & $\begin{array}{l}\text { Influence of soil on fecal indicator } \\
\text { in tidally influenced environment }\end{array}$ \\
\hline Frias-Lopez et al. (2002) & $\begin{array}{l}\text { Clostridium, Campylobacter, } \\
\text { Arobacter }\end{array}$ & $\begin{array}{l}\text { Pathogen partitioning was found } \\
\text { in surface and overlying water }\end{array}$ & $\begin{array}{l}\text { Bacterial communities partitioning } \\
\text { between sea water, dead coral surface }\end{array}$ \\
\hline $\begin{array}{l}\text { Chandran and } \\
\text { Hatha (2005) }\end{array}$ & E. coli, Salmonella & $\begin{array}{l}\text { E. coli shows better survival } \\
\text { capacity than Salmonella }\end{array}$ & Relative survival in microcosm studies \\
\hline Baker-Austin et al. (2009) & Vibrio vulnificus & $\begin{array}{l}\text { Prevalence of antibiotic } \\
\text { resistance in a human pathogen }\end{array}$ & $\begin{array}{l}\text { Multi-site analysis shows widespread } \\
\text { antibiotic resistance in pathogens }\end{array}$ \\
\hline
\end{tabular}

of fecal bacteria, and the removal of wrack deposits from inter-tidal zones can improve the water quality of adjacent coastal waters.

Similar to the coastal environment, increasing waterborne pathogen levels in estuaries are a serious threat to public health. Human activities can impact estuary pathogen levels when they are adjacent to populated areas, and often provide a means of transportation and substantial recreation (Schriewer et al. 2010; Pachepsky and Shelton 2011). The most common pathogens, previously identified in estuaries by Rhodes and Kator (1990), were Vibrio cholerae, Giardia, Cryptosporidium, Salmonella, and Campylobacter spp. As shown in Table 1, the presence of various pathogens (e.g., E. coli, C. perfringens,
Clostridium, Salmonella) has been reported in many previous studies. Municipal point sources are the primary cause of pathogen contamination in estuaries. Urban water disposed through combined sewer outflows is the cause of approximately $12 \%$ of estuary impairments in the U.S. (Arnone and Walling 2007). Pathogens, including Vibrio vulnificus which carries the highest fatality rate of any food-borne pathogen in the U.S., were detected in the Gulf of Mexico Estuary (Lipp et al. 2001; Baker-Austin et al. 2009). Several studies discovered that bed sediment plays a vital role (i.e., with the release of particle-attached pathogens from bed sediment to a water column through a resuspension process) for the persistence and transport of pathogens in the estuaries (Smith et al. 1978; Desmarais 
et al. 2002). Previous studies have shown that pathogen growth and decay are influenced by environmental conditions. For instance, a study by Chandran and Hatha (2005) revealed that sunlight is a major factor that influences survival of pathogens like E. coli and S. typhimurium in the estuarine water.

\section{Groundwater}

Groundwater is heavily used all over the world as the primary source of domestic drinking water supplies, and contaminated groundwater certainly enhances risk to public health. Nationally, $40 \%$ of the U.S. domestic water supply originates from groundwater, and over 40 million people use groundwater as their drinking water via private wells (Alley et al. 1999). Groundwater pathogen contamination has led to numerous disease outbreaks in the U.S.; for example, at least 46 outbreaks of disease occurred between 1992 and 1999, resulting in 2,739 cases of illness and several deaths (John and Rose 2005). These are reported cases; due to underdiagnosis and underreporting, the actual morbidity is almost certainly higher.

Several studies have shown that microbial pathogens, such as Salmonella, E. coli, S. faecalis, and enteroviruses are relatively stable in groundwater (Bittion et al. 1983; Schijven and Hassanizadeh 2000; Pang et al. 2004) (Table 2). Controlling groundwater pathogen contamination has recently been emphasized in many countries, as pathogens can survive up to 400 days depending on the soil temperature (Nevecherya et al. 2005; Filip and Demnerova 2009). For example, identifying sources of groundwater pathogen contamination has received significant attention in France (Grisey et al. 2010). Many studies reported that health risks caused by chlorine-resistant protozoans, such as Cryptosporidium spp. (Ferguson et al. 2003; Kay et al. 2007; Kay et al. 2008), are considerable. One of the major concerns is that wetlands without lining might cause pathogen contamination of groundwater (Kay et al. 2007). Similar concerns have been expressed in the United Kingdom by water regulators. The European Union (EU) has also emphasized protecting groundwater from pathogen contamination. Pathogen-contaminated groundwater can cause pollution in coastal environments. For example, a study of Buttermilk Bay has shown that groundwater is capable of transporting a large quantity of pathogens from surface to sub-surface water either by direct discharge or by discharge to rivers flowing into the bay (Moog 1987; Weiskel et al. 1996). The risk of contaminating groundwater particularly increases in areas where shallow aquifers exist. In these situations it is more likely that contaminated surface water or water from septic tanks can reach groundwater (Weiskel et al. 1996). Precipitation events are likely to increase groundwater pathogen contamination because of contaminated ground water recharge.
Pathogen contamination (e.g., bacteria, protozoa, and viruses) poses a serious risk in water resources. The transport of pathogens from surface water to groundwater increases the vulnerability of groundwater (Jin and Flury 2002). These authors reported that $70 \%$ of the water-borne microbial illness outbreaks in the United States have been associated with ground water. Pathogens such as viruses are much smaller than bacteria and protozoa, and many can potentially reach groundwater through porous soil matrices. Jin and Flury (2002) reviewed the fate and transport of viruses in porous media to understand mechanisms and modeling of virus sorption, and concluded that factors such as solution chemistry, virus properties, soil properties, temperature, and association with solid particle influences virus survival, transport, and sorption in porous media. Pang (2009) studied microbial removal rates in subsurface media, and reported that soil types considerably influence microbial removal rates. For instance, volcanic soils, pumice sand, fine sand, and highly weathered aquifer rocks showed high removal rates. The author found that microbial removal rates were inversely correlated with infiltration rates and transport velocity.

Considerable work recently has been done towards understanding pathogen transport in the vadose zone (Wang et al. 2014a; 2014b; Unc and Goss 2004; Darnault et al. 2004). Groundwater can be contaminated by seepage and percolation of contaminated water from the vadose zone (Darnault et al. 2004). The macropores of agricultural land are also known to play a considerable role in polluting groundwater, particularly from fields where manure is applied (Jamieson et al. 2002). Unc and Goss (2004) evaluated the influence of manure on the transport of bacteria from land receiving manure to water resources. These authors reported that manure application in the land influences pathogen transport in the vadose zone. The presence of straw and coarse organic matter influences the persistence of bacteria, and manure application changes the physical configuration of soil, the soil chemistry, and the properties of the microbial cells, which control the survival and persistence of bacteria in soils. Another recent study by Wang et al. (2014) assessed the transport of $E$. coli in soils with preferential flow. The authors reported that a decrease in macropore length resulted in a decreased apparent saturated hydraulic conductivity of the macropore and an increase in the mass transfer. Wang et al. (2014a; 2014b) concluded that macropore length has a considerable influence on preferential transport of E. coli.

\section{Reservoirs and lakes}

Previous studies have shown the presence of many pathogens in lakes and reservoirs (Table 2), and that these pathogens can pose risks to human health. In many countries surface reservoirs serve as the main source 
Table 2 Pathogen contamination in freshwater environment (ground water, rivers and lakes and reservoirs)

\begin{tabular}{|c|c|c|c|}
\hline Author(s) year & Organisms & Results & Study remarks \\
\hline \multicolumn{4}{|l|}{ Groundwater } \\
\hline Bitton et al. (1983) & $\begin{array}{l}\text { Salmonella, E. coli, S. faecalis, } \\
\text { enteroviruses }\end{array}$ & $\begin{array}{l}\text { S. faecalis decay rate was similar } \\
\text { to viruses }\end{array}$ & Survival of pathogens in groundwater \\
\hline Schijven and Hassanizadeh (2000) & Viruses & $\begin{array}{l}\text { Viruses attachment with soil was } \\
\text { influenced by pH, and favorable } \\
\text { sites }\end{array}$ & $\begin{array}{l}\text { Soil passage impacts on virus removal } \\
\text { at field-scale }\end{array}$ \\
\hline Pang et al. (2004) & E. coli and F-RNA phages & $\begin{array}{l}\text { Pathogens were sorbed in aquifer } \\
\text { material }\end{array}$ & Transport of E. coli and F-RNA phages \\
\hline Nevecherya et al. (2005) & $\begin{array}{l}\text { Salmonella, viruses, E. coli, } \\
\text { shigellos }\end{array}$ & $\begin{array}{l}\text { Mathematical model was derived } \\
\text { for temperature depends inactivation } \\
\text { rate }\end{array}$ & $\begin{array}{l}\text { Pathogenic bacteria and viruses survival } \\
\text { in groundwater }\end{array}$ \\
\hline Filip and Demnerova (2009) & $\begin{array}{l}\text { Bacillus megaterium and } \\
\text { Staphylococcus }\end{array}$ & Pathogens survived 10 to 100 days & $\begin{array}{l}\text { Pathogens survival in groundwater; FT-IR } \\
\text { characterization }\end{array}$ \\
\hline Grisey et al. (2010) & $\begin{array}{l}\text { Total coliforms, E. coli, } \\
\text { Enterococci, Pseudomonas } \\
\text { aeruginosa, Salmonella and } \\
\text { Staphylococcus aureus }\end{array}$ & $\begin{array}{l}\text { Bacterial density monitoring coupled } \\
\text { with artificial trace experiments proved } \\
\text { useful in locating pathogens sources }\end{array}$ & $\begin{array}{l}\text { Pathogens survival in groundwater and } \\
\text { landfill leachate }\end{array}$ \\
\hline \multicolumn{4}{|l|}{ Rivers } \\
\hline Chin (2010) & Fecal coliform & Summer and rainfall raises pathogens & Urban areas impacts on stream pathogens \\
\hline Smith et al. (1973) & $\begin{array}{l}\text { Salmonella, fecal coliforms, } \\
\text { streptococci }\end{array}$ & $\begin{array}{l}\text { Salmonella decline was close to fecal } \\
\text { coliform }\end{array}$ & Usefulness of indicators organisms \\
\hline Burton et al. (1987) & $\begin{array}{l}\text { Pseudomonas aeruginosa, } \\
\text { Salmonella newport, E. coli }\end{array}$ & $\begin{array}{l}\text { Clay in sediments improves E. coli } \\
\text { survival }\end{array}$ & $\begin{array}{l}\text { Survival of pathogens in fresh water } \\
\text { sediments }\end{array}$ \\
\hline Smith et al. (1987) & E. coli, Fecal bacteria & $\begin{array}{l}\text { U.S. rivers shows decline in fecal } \\
\text { indicator }\end{array}$ & Water quality assessment from 1974 to 1981 \\
\hline Terzieva and McFeters (1991) & $\begin{array}{l}\text { E. coli, Campylobacter jejuni, } \\
\text { Yersinia enterocolitica }\end{array}$ & $\begin{array}{l}\text { Temperate zone surface water serve } \\
\text { as a rersisitent verhicle in transimsision } \\
\text { of bacteria between animals and } \\
\text { humans }\end{array}$ & $\begin{array}{l}\text { Survival and injury study of bacteria in } \\
\text { agricultural surface water }\end{array}$ \\
\hline Terzieva and McFeters (1991) & $\begin{array}{l}\text { Yersinia enterocolitica and } \\
\text { E. coli }\end{array}$ & $\begin{array}{l}\text { Experimental design and environmental } \\
\text { play major role in pathogens survival }\end{array}$ & $\begin{array}{l}\text { Survival in stream water, comparison } \\
\text { between field and lab studies }\end{array}$ \\
\hline Fraser et al. (1998) & Fecal coliform & Model predicted pathogens & Modelling non-point source pollution \\
\hline \multicolumn{4}{|l|}{ Lakes and reservoirs } \\
\hline Beaver and Crisman (1989) & Ciliates & Grazing habits of ciliates are discussed & Predators roles in fresh water \\
\hline Rubentschik et al. (1936) & Serratia marcescens & $\begin{array}{l}\text { Adsorption of bacteria could be } \\
\text { questionable }\end{array}$ & Adsorption of bacteria in salt lakes \\
\hline Mac Kenzie et al. (1994) & Cryptosporidium & $\begin{array}{l}\text { C. oocysts study passes through the } \\
\text { filtration system of water supply }\end{array}$ & $\begin{array}{l}\text { Contaminated water from Milwaukee } \\
\text { lake caused outbreak }\end{array}$ \\
\hline Wcislo and Chrost (2000) & E. coli & Predators controlled pathogen levels & $\begin{array}{l}\text { Survival of pathogens in man-made } \\
\text { reservoir }\end{array}$ \\
\hline Kistemann et al. (2002) & $\begin{array}{l}\text { E. coli, coliform, fecal } \\
\text { streptococcal, and Clostridium } \\
\text { perfringens }\end{array}$ & $\begin{array}{l}\text { Most of the pathogens increases during } \\
\text { extreme runoff events }\end{array}$ & $\begin{array}{l}\text { Microbial load in drinking water reservoir } \\
\text { during rainfall events }\end{array}$ \\
\hline Howe et al. (2002) & Cryptosporidium oocysts & $\begin{array}{l}\text { Animal feces was a major source of } \\
\text { pathogens }\end{array}$ & $\begin{array}{l}\text { Water supply's oocysts caused outbreak } \\
\text { in northern England }\end{array}$ \\
\hline Ishii et al. (2006) & E. coli & E. coli survived longer in soil & $\begin{array}{l}\text { Presence and growth of E. coli in Lake } \\
\text { superior watershed }\end{array}$ \\
\hline
\end{tabular}

of drinking water, and these surface water bodies are often vulnerable to pathogen contamination (Kistemann et al. 2002). In the developed world, although there is increased awareness of water treatment for pathogen contamination and water quality, outbreaks of water-borne disease via public water supplies continue to be reported (Gibson et al. 1998; Howe et al. 2002; Brookes et al. 2004).

In the past, more than 403,000 residents of the greater Milwaukee, Wisconsin area experienced gastrointestinal illnesses due to infection with the parasite Cryptosporidium 
parvum following contamination of the city's water supply, which was associated with inadequate filtration of contaminated water from Lake Michigan (Mac Kenzie et al. 1994; Cicirello et al. 1997). In the 1990s, Cryptosporidiosis became the most common cause of outbreaks associated with public drinking water supplies in the United Kingdom (Howe et al. 2002). In developing countries, diseases such as diarrhea and cholera are the leading cause of morbidity (Nelson et al. 2009). Overall, diarrhea associated with drinking contaminated water is responsible for 2 to 2.5 million deaths annually (Fenwick 2006). In lakes and reservoirs, increased pathogens are often associated with storm events, and the stream inflow is considered to be the major source of pathogens during storm events. Elevated flows in rivers most likely agitate bed sediment, which causes enhancement of pathogen levels of the water column (Jamieson et al. 2005a; Jamieson et al. 2005b; Pandey and Soupir 2013; Bai and Lung 2005). During the rainy season, the influx of contaminated water from rivers to lakes and reservoirs can substantially increase pathogen levels (Kistemann et al. 2002). The quantity of pathogen influxes from tributaries of lakes and reservoirs during the rainy season is of particular importance in determining pathogen transport and distribution (Brookes et al. 2004).

\section{Rivers}

Pathogen contamination is a major cause of stream impairments. The sources of impairment and health risks induced by water-borne pathogens are extensively reported (Table 2). In the U.S. pathogen contamination is the leading cause of stream water pollution. The EPA's National Water Quality Inventory Report suggests that about 53\% of the assessed rivers are impaired, and a majority of them are contaminated by pathogens (U.S. EPA 2012a). The cost to implement the total maximum daily load (TMDL) plans to improve stream water is estimated as $\$ 0.9$ to $\$ 4.3$ billion per year (U.S. EPA 2010b).

Pathogen influxes into rivers from agricultural lands (Figure 4) are the main cause of stream impairments (Chin 2010; U.S. EPA 2012a). A weak understanding of pathogen transport from agricultural lands to rivers is considered to be a major challenge in implementing and deriving suitable land management practices capable of improving stream water quality. For instance, despite common knowledge that agricultural land's non-point source pollution is a leading cause of stream impairment, it is difficult to identify points of origin of pathogens and the pathways by which they enter streams. As an example, pathogens are likely to enter rivers from many potential sources, including lateral inputs from pastures and riparian zones, influx of pathogen-contaminated groundwater, direct deposit of fecal matter from livestock and wildlife, discharge of contaminated sanitary sewer flows, and wastewater treatment plant effluents. In rainy events, pathogens in rivers are influenced by fresh input from watersheds as well as sub-surface flow. In addition, the resuspension of legacy pathogens from bed sediments can considerably increase pathogen levels (Cho et al. 2010; Droppo et al. 2009; Jamieson et al. 2005b; Kiefer et al. 2012; Nagels et al. 2002; Muirhead et al. 2004; Kim et al. 2010; Smith et al. 2008).

Controlling pathogen contamination from livestock/ wildlife to streams is challenging (Terzieva and McFeters 1991). For example, it is doubtful that pathogen contamination can be prevented by fencing off riparian buffers, and even if buffers are useful in controlling stream water pathogens, it is not certain what their width must be (Nagels et al. 2002). There are review studies that elaborate on stream water pathogen contamination (Fraser et al. 1998; Jamieson et al. 2004; Pachepsky et al. 2006).

Many studies have emphasized the use of mathematical models to understand pathogen transport from agricultural land to rivers (Kim et al. 2010; Muirhead et al. 2004; Jamieson et al. 2005a; Jamieson et al. 2005b). Previous studies (Gerba and Smith 2005; Pandey et al. 2012b; Pandey and Soupir 2013; Pachepsky and Shelton 2011; Martinez et al. 2014) have emphasized the need to improve existing models for calculating the fate and transport of pathogens at the watershed scale. Currently, empirical as well as mechanistic models are being used to calculate microbial fate and transport (Muirhead and Monaghan 2012). Numerous studies are available for exploiting watershed scale models such as WATFLOOD (Dorner et al. 2006), the Soil and Water Assessment Tool (SWAT) (Neitsch et al. 2005), the Spatially Explicit Deliver Model (SEDMOD) (Fraser 1999), and KINEROS/STWIR (Guber et al. 2011) for predicting pathogen transport. Though numerous watershed scale models are available, which can be exploited for calculating pathogen transport at watershed scale, considerable difficulties exist while using the models (Pandey et al. 2012b; Pandey and Soupir 2013). For instance, correctly identifying the model input parameter values is a daunting task. Recently, considerable emphasis has been given to understand the sensitivity of the input parameters to the model output (Martinez et al. 2014; Parajuli et al. 2009).

When implementing watershed scale models for predicting pathogen transport, difficulties related to the selection of model input parameters are common (Martinez et al. 2014). A study by Parajuli et al. (2009) evaluated the sensitivity of fecal coliform bacteria loads modeled with SWAT, and the authors reported that many of the parameters (e.g., bacterial die-off rates, the temperature adjustment factor) were insensitive to the model output. Similarly, Coffey et al. (2010) reported that initial concentration of $E$. coli and the bacterial partition coefficient parameters of the SWAT model were overly 


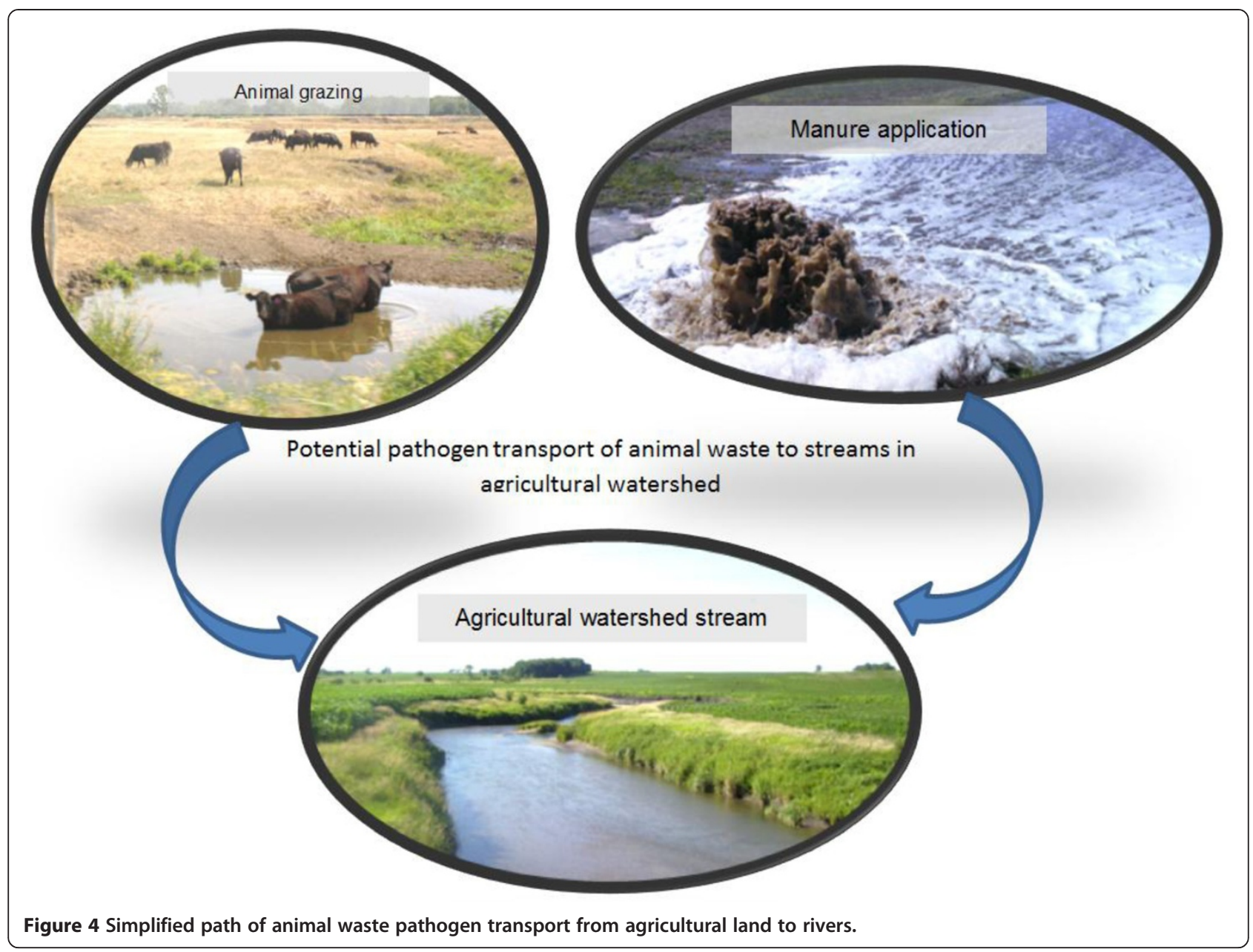

sensitive in affecting the model's output. Another recent study by Martinez et al. (2014) evaluated the KINEROS/ STWIF model input parameter sensitivities to the output. These authors reported that environmental controls such as soil saturation, rainfall duration, and rainfall intensity had the most sensitivity, while parameters such as soil and manure properties were the least sensitive in affecting model output. Many previous studies (Pandey and Soupir 2012a, 2012b; Kim et al. 2010; Martinez et al. 2014; Parajuli et al. 2009) reported that identification and selection of model input parameters are major challenges when implementing the model for predicting fate and transport of pathogens at the watershed scale.

\section{Blooming of cyanobacteria}

While water-borne pathogens are a serious concern, excessive algal bloom (Figure 5) in water resources can potentially limit their uses for recreation activities as well as for drinking water. Cyanobacteria (blue-green algae) have unique roles in oxygenation of the atmosphere (Hofer 2013); however, their excessive growth or dense algal bloom in water resources diminishes the quality and quantity of light in the water column (U.S. EPA 2014b). When blooms are excessive, the risk of toxin contamination (released by harmful algal bloom (HABs)) is likely to be elevated. The HAB includes many types of algal taxa such as dinoflagellates, diatoms, and cyanobacteria. Eutrophication caused by excessive algal bloom can cause fish kills and reduce the diversity of aquatic life (U.S. EPA 2014b). In hypoxic water, dissolved oxygen levels can be less than $2-3$ ppm (U.S. EPA 2014c). For example, in the hypoxic zone in the northern Gulf of Mexico, an area along the Louisiana-Texas coast, less than $2 \mathrm{ppm}$ of dissolved oxygen concentration has been reported. This is believed to be caused by excess nutrients delivered from the Mississippi River, in combination with seasonal stratification of Gulf waters (U.S.G.S., 2014). The largest U.S. hypoxic zone, which occurred in 2002 in the Gulf of Mexico, was about 13,518 square kilometers (U.S. G.S. 2012).

Freshwater cyanobacterial blooms produce highly potent cyanotoxins and cyanobacterial HABs, which can affect the liver, nervous system, and skin (U.S. EPA 2014b). Cyanobacterial blooms can be potentially detrimental to 


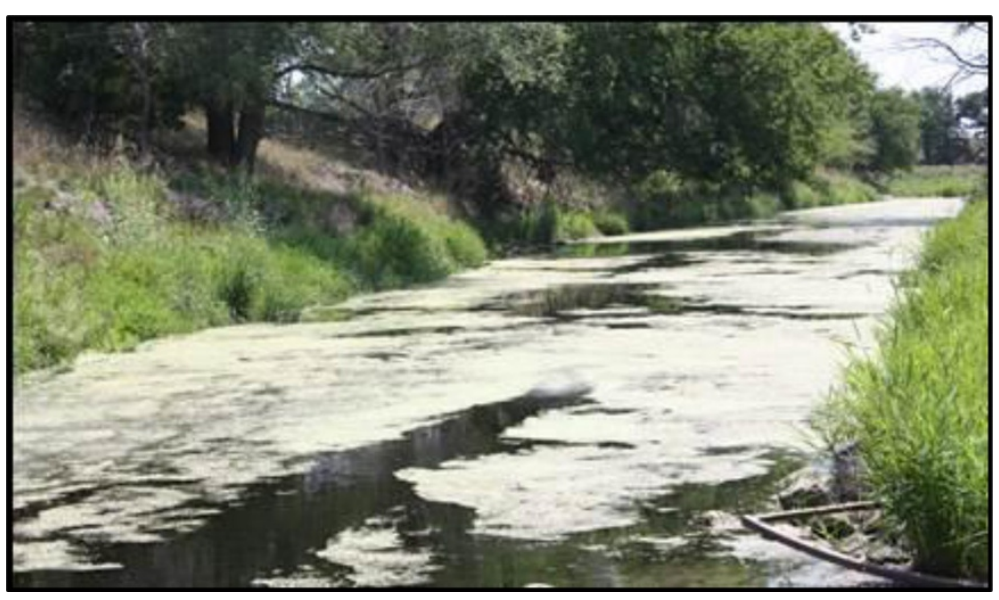

Figure 5 Algal bloom in Squaw Creek, lowa, U.S.

human and animal health, aquatic habitats, and aquaculture industries (Kaloudis et al. 2013; Carmichael 2001; Falconer 2005; Codd et al. 1999). Previous studies (Mackintosh et al. 1990; Yoshizawa et al. 1990) have shown that microcystins (i.e., cynotoxins) are hepatotoxic and act as tumor promoters through the inhibition of protein phosphatases, which play a key role in cellular regulation. Eutrophic water conditions combined with warm surface water temperatures $\left(15-30^{\circ} \mathrm{C}\right)$ can potentially enhance cyanobacterial blooms in water (Oikonomou et al. 2012; Vareli et al. 2009). Currently more than 400 hypoxic zones exist in the world affecting 245,000 square kilometers (Diaz and Rosenberg 2008). These dead zones in coastal waters have spread exponentially since the 1960s and have considerably impacted ecosystems. The increase in these dead zones is likely to be influenced by climate change. Various factors such as how climate change affects water-column stratification and how nutrient runoff affects organic matter production will determine further expansion of the dead zones (Diaz and Rosenberg 2008). For instance, climate predictions of the Mississippi River basin indicate a $20 \%$ increase in river discharge, which will enhance nutrient loading and result in expansion of the oxygen depleted area (IPCC 2007). Considering the importance of fresh water, estuarine, and marine environment to public health and aquatic life, identifying approaches capable of controlling excessive algal blooms is required before these dead zones spread globally.

\section{Impact of water resources development}

Water resources development involves altering the natural flow path of rivers and lakes, as well as designing irrigation schemes and dams. These activities have been alleged to be responsible for causing new diseases and enhancing health risks (Fenwick 2006; Steinmann et al. 2006).

The influence of water resources development in spreading diseases, such as schistosomiasis, a parasitic disease which is ranked second only to malaria with regard to the number of people infected, has been reported extensively; one estimate says that about 103 million out of 779 million infected people live in close proximity to large reservoirs and irrigation schemes (Steinmann et al. 2006).

Designing dams and irrigation schemes in tropical and subtropical climate zones has often resulted in disease outbreaks caused by water-borne pathogens. Consider, for example, the Sennar Dam on the Blue Nile River and Sudan's Gezira Scheme, the world's largest irrigation project. Because of the dam's commercial success, irrigation in the region has doubled from the 1940s and 1950s. After the 1950s, infections from malaria and schistosomiasis increased significantly, becoming the subject of the first integrated disease-control program, the Blue Nile Health Project, implemented from 1978 to 1990 . The project failed to have any impact in controlling the prevalence of schistosomiasis (Eltoum et al. 1993; Fenwick 2006; Steinmann et al. 2006). Another example is China's Three Gorges Dam, built across the Yangtze River and completed in 2009 , which created a $50,700 \mathrm{~km}^{2}$ reservoir and submerged more than 220 counties. Hotez et al. (1997) reported that the reservoir would produce environmental changes that could lead to the transmission of schistosomiasis in the area served by the dam. A recent study by Schrader et al. (2013) found major high risk areas for schistosomiasis occurrence in the large lakes and flood plain regions of the Yangtze River. Another study by Gray et al. (2012) reported that the Three Gorges Dam will likely to impact the transmission of schistosomiasis in China.

In the U.S., because of increasing concern for produce safety, pathogen-free irrigation water is attracting considerable attention (Martinez et al. 2014). Painter et al. (2013) reported that produce accounted for nearly half of food-borne illnesses in the U.S. between 1998 and 
2008. Growing concern about the safety of food and water will likely help in developing improved strategies while planning and designing large dams for irrigation purposes.

\section{Challenges and recommendations}

Infectious diseases caused by pathogens are the third leading cause of death in the United States, and the leading cause in the world (Binder et al. 1999). The past two decades have seen the emergence of many new pathogenic infectious diseases (Daszak et al. 2000). Many of these are caused by anthropogenic changes, such as water resources development, climate warming, and interactions between humans and animals, both domestic and wild (Krause 1994; Epstein 2001; Woolhouse 2002; Fenwick 2006; Schriewer et al. 2010).

Multidisciplinary knowledge about how ambient water bodies, wildlife, domestic animals, and human populations interact with and impact each other are crucial in dealing with future challenges. Generally, domestic animals, wildlife, and humans are considered to be major sources of water-borne pathogens; however, finding the specific culprit-the primary pathogen source-is challenging (Malakoff 2002). A watershed, for example, can have many pathogen sources, such as agricultural land, riparian areas, agricultural feeding operations, livestock, wildlife, and humans.

Developing models that are reliable in predicting pathogen survival and transport at the watershed scale can be helpful in implementing/evaluating the strategies for mitigating ambient water body pathogen levels. Evaluating the impacts of various environmental factors on pathogen survival in water resources is crucial. Various publications (i.e., Dorner et al. 2006; Kim et al. 2010; Rehmann and Soupir 2009; Droppo et al., 2011; Cho et al. 2010; Pandey et al. 2012b; Pandey and Soupir 2013) are available describing models capable of predicting pathogen contamination levels in ambient water bodies; however, further work is required to improve model predictions. The evaluation of predictions by existing models clearly demonstrates the need for improvement. Many pathogen transport models use only temperature-induced mortality and growth, and do not include interactions among other environmental factors (e.g., $\mathrm{pH}$, nutrients, DO, solar radiation); future inclusion of these environmental factors will likely to improve the model predictions.

Typically most studies have relied on E. coli and other indicator bacteria to indicate pathogen levels in water. Although widely used in monitoring contamination levels, E. coli alone can lead to mercurial and misleading information (Gordon 2001). Schriewer et al. (2010) suggested that with improved pathogen detection technology (i.e., PCR-based detection) an indicator organism, such as $E$. coli, can be sufficiently accurate in most cases. Overall, improving technology to identify causative agents more accurately, creating standard epidemiological data for diseased populations, and enhancing the knowledge of disease dynamics can improve the understanding of risks caused by interactions among various populations (Harvell et al. 1999; Daszak et al. 2000; Harvell et al. 2002).

In the past, a number of studies on pathogen contamination have been conducted on a scale where the conditions of ambient water bodies were simulated in laboratories. These studies are helpful in understanding pathogen behavior only up to a point. For enhancing the understanding of pathogen interactions in the environment, more emphasis should be given to field-scale studies.

\section{Conclusions}

This review examines studies from various disciplines to understand pathogen contamination in ambient water bodies. The worldwide prevalence of pathogen contamination is a serious concern, and enhancing the understanding of major pathogen sources and their significant impacts on water resources is crucial. A considerable number of studies on pathogen contamination have been conducted on a laboratory-scale; more emphasis should be given to field-scale studies for enhancing the understanding of pathogen interactions in the environment. Developing new models, and improving existing modeling approaches commonly used for predicting water-borne pathogen levels will likely to help in assessing pathogen contamination at watershed-scale. Considering the limited ability of existing models to predict pathogen contamination, improvement and development of new models are needed so that pathogen levels can be predicted more accurately. Integrating knowledge from multiple fields (e.g., hydrology, microbiology, and ecology) would increase the understanding of pollution levels and potential causes of pollution, and can also help devise long-term strategies to improve water quality.

\section{Competing interest}

The authors declare that they have no competing interests.

\section{Acknowledgment}

The authors thank the Division of Agriculture and Natural Resources and Veterinary Medicine Extension, University of California, Davis, and National Science Foundation (award No. CBET-0967845) for supporting this work.

\section{Author details}

'Department of Population Health and Reproduction, University of California, Davis, California, USA. ²Department of Agricultural and Biosystems Engineering, lowa State University, Ames, lowa, USA. ${ }^{3}$ Department of Biological and Agricultural Engineering \& Zachry Department of Civil Engineering, Texas A \& M University, College Station, Texas, USA.

Received: 3 May 2014 Accepted: 27 May 2014

Published online: 28 June 2014 


\section{References}

Alley WM, Reilly TE, Franke OL (1999) Sustainability of Groundwater Resources. U. S. Geological Survey (U.S.GS), Denver, CO

Arnone RD, Walling JP (2007) Waterborne pathogens in urban watersheds. J Water Health 5(1):149-162

Bai S, Lung WS (2005) Modeling sediment impact on the transport of fecal bacteria. Water Res 39:5232-5240

Baker-Austin C, McArthur J, Lindell A, Wright M, Tuckfield R, Gooch J, Warner L, Oliver J, Stepanauskas R (2009) Multi-site analysis reveals widespread antibiotic resistance in the marine pathogen: Vibrio vulnificus. Microb Ecol 57(1):151-159

Beaver JR, Crisman TL (1989) The role of ciliated protozoa in pelagic freshwater ecosystems. Microb Ecol 17(2):111-136

Binder S, Levitt AM, Sacks JJ, Hughes JM (1999) Emerging infectious diseases: public health issues for the 21st Century. Science 284(5418):1311-1313

Bitton G, Farrah SR, Ruskin RH, Butner J, Chou YJ (1983) Survival of pathogenic and indicator organisms. Groundwater 21(4):405-410

Bradford SA, Morales VL, Zhang W, Harvey RW, Packman Al, Mohanram A, Welty C (2013) Transport and fate of microbial pathogens in agricultural settings. Crit Rev Env Sci Tec 43:775-893

Brookes JD, Antenucci J, Hipsey M, Burch MD, Ashbolt NJ, Ferguson C (2004) Fate and transport of pathogens in lakes and reservoirs. Environ Int 30(5):741-759

Burton GA, Gunnison D, Lanza GR (1987) Survival of pathogenic bacteria in various freshwater sediments. Appl Environ Microbiol 53(4):633-638

Cabelli VJ (1983) Public health and water quality significance of viral diseases transmitted by drinking water and recreational water. Water Sci Technol 15(5):1-15

Carmichael WW (2001) Health effects of toxin-producing cyanobacteria: the CyanoHABs. Hum Ecol Risk Assess 7:1393-1407

Centers for Disease Control and Prevention (CDC) (2011) Cholera in Haiti: One Year Later., http://www.cdc.gov/haiticholera/haiti_cholera.htm (accessed on 5/23/2014)

Centers for Disease Control and Prevention (CDC) (2014) Salmonella., http://www. cdc.gov/salmonella/general/ (accessed on 4/28/2014)

Chandran A, Mohamed Hatha AAM (2005) Relative survival of Escherichia coli and Salmonella typhimurium in a tropical estuary. Water Res 39(7):1397-1403

Chin DA (2010) Linking pathogen sources to water quality in small urban streams. J Environ Eng 136(2):249-253

Cho KH, Pachepsky YA, Kim JH, Guber AK, Shelton DR, Rowland R (2010) Release of Escherichia coli from the bottom sediment in a first-order creek: Experiment and reach-specific modeling. J Hydrol 391(3-4):322-332

Cicirello HG, Kehl KS, Addiss DG, Chusid MJ, Glass Rl, Davis JP, Havens PL (1997) Cryptosporidiosis in children during a massive waterborne outbreak in Milwaukee, Wisconsin: clinical, laboratory and epidemiologic findings. Epidemiol Infect 119(1):53-60

Codd G, Bell S, Kaya K, Ward C, Beattie K, Metcalf J (1999) Cyanobacterial toxins, exposure routes and human health. Eur J Phycol 34:405-415

Coffey R, Cummins EO, Flaherty V, Cormican M (2010) Pathogen sources estimation and scenario analysis using the Soil and Water Assessment Tool (SWAT). Hum Ecol Risk Assess 16(4):913-933

Colwell RR (1996) Global climate and infectious disease: The Cholera Paradigm. Science 274(5295):2025-2031

Craun GF, Fraun MF, Calderon RL, Beach MJ (2006) Waterborne outbreaks reported in the United States. J Water Health 4:19-30

Darnault CJD, Steenhuis TS, Garnier P, Kim YJ, Jenkins MB, Ghiorse WC, Baveye PC, Parlange JY (2004) Preferential flow and transport of Cryptosporidium parvum oocysts through the vadose zone: Experiments and modeling. Vadose Zone J 3(2):262-270

Daszak P, Cunningham AA, Hyatt AD (2000) Emerging infectious diseases of wildlife - threats to biodiversity and human health. Science 287:443-449

Desmarais TR, Solo-Gabriele HM, Palmer CJ (2002) Influence of soil on fecal indicator organisms in a tidally influenced subtropical environment. Appl Environ Microbiol 68(3):1165-1172

Diaz RJ, Rosenberg R (2008) Spreading dead zones and consequences for marine ecosystems. Science 321:926-929

Dickerson JW, Crozier JB, Hagedorn G, Hassall A (2007) Assessment of 16 s-23srDNA interagenic spacer regions in Eterococcus spp. for microbial source tracking. J Environ Qual 36:1661-1669

Diffey BL (1991) Solar ultraviolet-radiation effects on biological-systems. Phys Med Biol 36(3):299-328
Dorner SM, Anderson WB, Slawson RM, Kouwen N, Huck PM (2006) Hydrologic modeling of pathogen fate and transport. Environ Sci Technol 40(15):4746-4753

Droppo IG, Liss SN, Williams D, Nelson T, Jaskot C, Trapp B (2009) Dynamic existence of waterborne pathogens within river sediment compartments: Implications for water quality regulatory affairs. Environ Sci Technol 43(6):1737-1743

Droppo IG, Krishnappan BG, Liss SN, Marvin C, Biberhofer (2011) Modeling sediment-microbial dynamics in the South Nation River, Ontario, Canada: Towards the prediction of aquatic and human health risk. Water Res 45:3797-3809

Dufour A (1984) Health Effects Criteria for Fresh Recreational Waters. Toxicology and Microbiology Division, U.S. Environmental Protection Agency Report EPA- 600-1-84-2004. , Cincinnati, OH

Edge TA, Hill S, Seto P, Marsalek J (2010) Library-dependent and library independent microbial source tracking to identify spatial variation in faecal contamination sources along a Lake Ontario beach (Ontario, Canada). Water Sci Technol 62:719-727

Eltoum IA, Sulaiman SM, Elturabi H, Mahgoub E, Homeida MMA (1993) Infection with Schistosoma-Mansoni in 2 different endemic areas - a comparative population - based study in Elzidab and Gezira-Managil irrigation schemes, Sudan. J Trop Med Hyg 96(2):100-106

Epstein PR (2001) Climate change and emerging infectious diseases. Microbes Infect 3(9):747-754

Falconer IR (2005) Is there a human health hazard from microcystins in the drinking water supply? Acta Hydrochim Hydrobiol 33:64-71

Fayer R, Trout JM (2005) Zoonotic protists in the marine environment. In: Belkin S and Colwell RR (ed) Oceans and Health: Pathogens in the Marine Environment. Springer, New York, U.S, pp 143-163

Fenwick A (2006) Waterborne Infectious Diseases-Could they be consigned to History? Science 313:1077-1081

Ferguson C, Husman AMD, Altavilla N, Deere D, Ashbolt N (2003) Fate and transport of surface water pathogens in watersheds. Crit Rev Environ Sci Technol 33(3):299-361

Filip Z, Demnerova K (2009) Survival in groundwater and FT-IR characterization of some pathogenic and indicator bacteria. In: Jones JAA, Vardanian TG, Hakopian C (ed) Threats to Global Water Security. Springer, Dordrecht, The Netherlands, pp 117-122

Fraser RH (1999) SEDMOD: A GIS-based delivery model for diffuse source pollutants. PhD dissertation, School of Forestry and Environmental Studies, Yale University

Fraser RH, Barten PK, Pinney DAK (1998) Predicting stream pathogen loading from livestock using a geographical information system-based delivery model. J Environ Qual 27(4):935-945

Frias-Lopez J, Zerkle AL, Bonheyo GT, Fouke BW (2002) Partitioning of bacterial communities between seawater and healthy, black band diseased, and dead coral surfaces. Appl Environ Microbiol 68(5):2214-2228

Gerba CP, McLeod JS (1976) Effect of sediments on the survival of Escherichia coli in marine waters. Appl Environ Microbiol 32(1):114-120

Gerba CP, Smith J (2005) Sources of pathogenic microorganisms and their fate during land application of wastes. J Environ Qual 34:42-48

Gibson CJ, Haas CN, Rose JB (1998) Risk assessment of waterborne protozoa: current status and future trends. Parasitology 117:S205-S212

Gordon DM (2001) Geographical structure and host specificity in bacteria and the implications for tracing the source of coliform contamination. Microbiology 147(5):1079-1085

Goyal SM, Gerba CP, Melnick JL (1977) Occurrence and distribution of bacterial indicators and pathogens in canal communities along Texas Coast. Appl Environ Microbiol 34(2):139-149

Grave AK, Hagedorn C, Brooks A, Hagedorn RL, Martin E (2007) Microbial source tracking in a rural watershed dominated by cattle. Water Res 41:3729-3739

Gray DJ, Thrift AP, Williams GM, Zheng F, Li Y-S, Guo J, Chen H, Wang T, Xu XJ, Zhu R, Zhu H, Cao CL, Lin DD, Zhao ZY, Li RS, Davis GM, McManus DP (2012) Five-year longitudinal assessment of the downstream impact on schistosomiasis transmission following closure of the Three Gorges Dam. PLoS Negl Trop Dis 6(4):e 1588, doi:10.1371/journal.pntd.0001588

Grisey E, Belle E, Dat J, Mudry J, Aleya L (2010) Survival of pathogenic and indicator organisms in groundwater and landfill leachate through coupling bacterial enumeration with tracer tests. Desalination 261(1-2):162-168

Guber AK, Pachepsky YA, Yakirevich AM, Shelton DR, Sadeghi AM, Goodrich DC, Unkrich CL (2011) Uncertainty in modelling of faecal coliform overland transport associated with manure application in Maryland. Hydrolical Process 25(15):2393-2404 
Harvell CD, Kim K, Burkholder JM, Colwell RR, Epstein PR, Grimes DJ, Hofmann EE, Lipp EK, Osterhaus AD, Overstreet RM, Porter JW, Smith GW, Vasta GR (1999) Emerging marine diseases-climate links and anthropogenic factors. Science 285(5433):1505-1510

Harvell CD, Mitchell CE, Ward JR, Altizer S, Dobson AP, Ostfeld RS, Samuel MD (2002) Climate warming and disease risks for terrestrial and marine biota. Science 296:2158-2162

Hipsey MR, Antenucci JP, Brookes JD (2008) A generic, process-based model of microbial pollution in aquatic systems. Water Resour Res 44(7), W07408

Hofer U (2013) Getting to the bottom of Cyanobacteria. Nat Rev Microbiol 11:818-819

Hotez PJ, Feng Z, Xu LQ, Chen MG, Xiao SH, Liu SX, Blair D, McManus DP, Davis GM (1997) Emerging and reemerging helminthiases and the public health of China. Emerg Infect Dis 3(3):303-310

Howe AD, Forster S, Morton S, Marshall R, Osborn KS, Wright P, Hunter PR (2002) Cryptosporidium oocysts in a water supply associated with a cryptosporidiosis outbreak. Emerg Infect Dis 8(6):619-624

Ibekwe AM, Murinda SE, Graves AK (2011) Genetic diversity and antimicrobial resistance of Escherichia coli from human and animal sources uncovers multiple resistances from human sources. PLoS One 6:e20819, doi:10.1371/journal.pone.0020819

Intergovernmental Panel for Climate Change (IPCC) (2007) IPCC Fourth Assessment Report, Summary for Policymakers, p 5

Ishii S, Ksoll WB, Hicks RE, Sadowsky MJ (2006) Presence and growth of naturalized Escherichia coli in temperate soils from Lake Superior watersheds. Appl Environ Microbiol 72(1):612-621

Jamieson R, Gordon R, Sharples K, Stratton G, Madani A (2002) Movement and persistence of fecal bacteria in agricultural soils and subsurface drainage water: A review. Can Biosyst Eng 44:1.1-1.90

Jamieson R, Gordon R, Joy D, Lee H (2004) Assessing microbial pollution of rural surface waters: A review of current watershed scale modeling approaches. Agric Water Manag 70(1):1-17

Jamieson R, Joy DM, Lee H, Kostaschuk R, Gordon R (2005a) Transport and deposition of sediment-associated Escherichia coli in natural streams. Water Res 39(12):2665-2675

Jamieson RC, Joy DM, Lee H, Kostaschuk R, Gordon RJ (2005b) Resuspension of sediment-associated Escherichia coli in a natural stream. J Environ Qual 34(2):581-589

Jin Y, Flury M (2002) Fate and transport of viruses in porous media. Adv Agron 77:39-102

John DE, Rose JB (2005) Review of factors affecting microbial survival in groundwater. Environ Sci Tech 39(19):7345-7356

Jordan EO, Russell HL, Zeit FR (1904) The longevity of the typhoid bacillus in water. J Infect Dis 1(4):641-689

Kaloudis T, Zervou S, Tsimeli K, Triantis TM, Fotiou T, Hiskia A (2013) Determination of microcystins and nodularin (cyanobacterial toxins) in water by LC-MS/MS. Monitoring of Lake Marathonas, a water reservoir of Athens, Greece. J Hazard Mater 263:105-115

Kapuscinski RB, Mitchell R (1983) Sunlight-induced mortality of viruses and Escherichia coli in coastal seawater. Environ Sci Technol 17(1):1-6

Kay D, Edwards AC, Ferrier RC, Francis C, Kay C, Rushby L, Watkins J, McDonald AT, Wyer M, Crowther J, Wilkinson J (2007) Catchment microbial dynamics: the emergence of a research agenda. Prog Phys Geogr 31(1):59-76

Kay D, Crowther J, Stampleton CM, Wyer MD, Fewtrell L, Anthony S, Bradford M, Edwards A, Francis CA, Hopkins M, Kay C, McDonald AT, Watkins J, Wilkinson $J$ (2008) Faecal indicator organism concentrations and catchment export coefficients in the UK. Water Res 42:2649-2661

Ketchum BH, Ayers JC, Vaccaro RF (1952) Processes contributing to the decrease of coliform bacteria in a tidal estuary. Ecology 33(2):247-258

Kiefer LA, Shelton DR, Pachepsky Y, Blaustein R, Santin-Duran M (2012) Persistence of E. coli introduced into streabe dsedient with goose, deer and bovine animal waste. Lett Appl Microbiol 55(5):345-353

Kim JW, Pachepsky YA, Shelton DR, Coppock C (2010) Effect of streambed bacteria release on E. coli concentrations: Monitoring and modeling with the modified SWAT. Ecol Model 221(12):1592-1604

Kistemann T, Classen T, Koch C, Dangendorf F, Fischeder R, Gebel J, Vacata V, Exner M (2002) Microbial load of drinking water reservoir tributaries during extreme rainfall and runoff. Appl Environ Microbiol 68(5):2188-2197

Krause RM (1994) Dynamics of emergence. J Infect Dis 170(2):265-271

Liang Z, He Z, Zhou X, Powell C, Yang Y, He LM, Stoffella PJ (2013) Impact of mixed land-use practices on the microbial water quality in a subtropical coastal watershed. Sci Total Environ 449:426-433
Lipp EK, Rodriguez-Palacios C, Rose JB (2001) Occurrence and distribution of the human pathogen Vibrio vulnificus in a subtropical Gulf of Mexico estuary. Hydrobiologia 460(1):165-173

Ma LP, Li B, Zhang T (2014) Abundant rifampin resistance genes and significant correlations of antibiotic resistance genes and plasmids in various environments revealed by metagenomic analysis. Appl Microbiol Biotechnol 98:5195-5204. doi:10.1007/s00253-014-5511-3

Mac Kenzie WR, Hoxie NJ, Proctor ME, Gradus MS, Blair KA, Peterson DE, Kazmierczak JJ, Addiss DG, Fox KR, Rose JB, Davis JP (1994) A massive outbreak in Milwaukee of Cryptosporidium infection transmitted through the public water supply. N Engl J Med 331(3):161-167

MacKintosh C, Beattie KA, Klumpp S, Cohen P, Codd GA (1990) Cyanobacterial microcystin-LR is a potent and specific inhibitor of protein phosphatases 1 and 2A from both mammals and higher plants. FEBS Lett 264:187-192

Malakoff D (2002) Water quality: microbiologists on the trail of polluting bacteria. Science 295(5564):2352-2353

Martinez G, Pachepsky YA, Whelan G, Yakirevich AM, Guper A, Gish T (2014) Rainfall-induced fecal indicator organisms transport from manured fields: Model sensitivity analysis. Environ Int 63:121-129

Moog PL (1987) The hydrogeology and freshwater influx of Buttermilk Bay, Massachusetts, with regard to the circulation of coliforms and pollutants: a model study and development of methods for general application, M.S. Thesis. Boston University, Boston, MA, p 166

Muirhead RW, Monaghan RM (2012) A two reservoir model to predict Escherichia coli losses to water from pastures grazed by dairy cows. Environ Int 40:8-14

Muirhead RW, Davies-Colley RJ, Donnison AM, Nagels JW (2004) Faecal bacteria yields in artificial flood events: quantifying in-stream stores. Water Res 38(5):1215-1224

Nagels JW, Davies-Colley RJ, Donnison AM, Muirhead RW (2002) Faecal contamination over flood events in a pastoral agricultural stream in New Zealand. Water Sci Technol 45(12):45-52

Nasser AM, Zaruk N, Tenenbaum L, Netzan Y (2003) Comparative survival of Cryptosporidium, coxsackievirus A9 and Escherichia coli in stream, brackishand sea waters. Water Sci Technol 47(3):91-96

Neitsch SL, Arnold JG, Kiniry JR, Williams JR, King KW (2005) Soil and water assessment tool: theoretical documentation, version 2005. Texas, U.S.A, Elsevier

Nelson EJ, Harris JB, Glenn Morris J, Calderwood SB, Camilli A (2009) Cholera transmission: the host, pathogen and bacteriophage dynamic. Nat Rev Microbiol 7(10):693-702

Nevecherya IK, Shestakov VM, Mazaev VT, Shlepnina TG (2005) Survival rate of pathogenic bacteria and viruses in groundwater. Water Resources 32(2):209-214

Oikonomou A, Katsiapi M, Karayanni H, Moustaka-Gouni M, Kormas KA (2012) Plankton microorganisms coinciding with two consecutive mass fish kills in a newly reconstructed lake. Sci World J 2012:1-14, doi:10.1100/2012/504135

Okun DA (1996) From cholera to cancer to cryptosporidiosis. J Environ Eng 122(6):453-458

Pachepsky YA, Shelton DR (2011) Escherichia coli and fecal coliforms in freshwater and estuarine sediments. Crit Rev Env Sci Tec 41(12):1067-1110

Pachepsky YA, Sadeghi AM, Bradford SA, Shelton DR, Guber AK, Dao T (2006) Transport and fate of manure-borne pathogens: Modeling perspective. Agric Water Manag 86(1-2):81-92

Painter JA, Hoekstra RM, Ayers T, Tauxe RV, Braden CR, Angulo FJ, Griffin PM (2013) Attribution of foodborne illnesses, hospitalizations, and deaths to food commodities by using outbreak data, United States, 1998-2008. Emerg Infect Dis 19(3):407-415

Pandey PK, Soupir ML (2012a) Non-point Source Pollution. Berkshire Encyclopedia of Sustainability: Ecosystem Management and Sustainability. Berkshire Publishing Group, LLC, Great Barrington, MA, U.S

Pandey PK, Soupir ML (2013) Assessing the impacts of E. coli laden streambed sediment on E. coli loads over a range of flows and sediment characteristics. J Am Water Resour Assoc 49(6):1261-1269

Pandey PK, Soupir ML, Rehmann CR (2012b) A model for predicting resuspension of Escherichia coli from streambed sediments. Water Res 46:115-126

Pang $L$ (2009) Microbial removal rates in subsurface media estimated from published studies of field experiments and large intact soil cores. J Environ Qual 38:1531-1559, doi:10.2134/jeq2008.0379

Pang L, Close M, Goltz M, Sinton L, Davies H, Hall C, Stanton G (2004) Estimation of septic tank setback distances based on transport of $E$. coli and F-RNA phages. Environ Int 29(7):907-921 
Parajuli PB, Douglas-Mankin KR, Barnes PL, Rossi CG (2009) Fecal bacteria source characterization and sensitivity analysis of SWAT 2005. Trans ASAE 52:1847-1858

Rao VC, Seidel KM, Goyal SM, Metcalf TG, Melnick JL (1984) Isolation of enteroviruses from water, suspended solids, and sediments from Galveston Bay: survival of poliovirus and rotavirus adsorbed to sediments. Appl Environ Microb 48(2):404-409

Rehmann CR, Soupir ML (2009) Importance of interactions between the water column and the sediment for microbial concentrations in streams. Water Res 43(18):4579-4589

Rhodes MW, Kator HI (1990) Effects of sunlight and autochthonous microbiota on Escherichia coli survival in an estuarine environment. Curr Microbiol 21(1):65-73

Rippey SR (1994) Infectious-diseases associated with molluscan shellfish consumption. Clin Microbiol Rev 7(4):419-425

Roberts MC, Soge OO, No D (2013) Comparison of multi-drug resistant environmental methicillin-resistant Staphylococcus aureus isolated from recreational beaches and high touch surfaces in built environment. Front Microbiol 4(74):1-8. doi:10.3389/fmicb.2013.00074

Rubentschik L, Roisin MB, Bieljansky FM (1936) Adsorption of bacteria in Salt Lakes. J Bacteriol 32(1):11-31

Rudolfs W, Falk LL, Ragotzkie RA (1950) Literature review on the occurrence and survival of enteric, pathogenic, and relative organisms in soil, water, sewage, and sludge, and on vegetation. Sewage Ind Wastes 22(10):1261-1281

Ruediger GF (1911) Studies on the self-purification of streams. Am J Public Health Assoc 1(6):411-415

Sayler GS, Nelson JD, Justice A, Colwell RR (1975) Distribution and significance of fecal indicator organisms in the Upper Chesapeake Bay. Appl Environ Microb 30(4):625-638

Schijven JF, Hassanizadeh SM (2000) Removal of viruses by soil passage: overview of modeling, processes, and parameters. Crit Rev Env Sci Tec 30(1):49-127

Schrader M, Hauffe T, Zhang Z, Davis GM, Jopp F, Remais JV, Wilke T (2013) Spatially explicit modeling of Schistosomiasis risk in eastern China based on a synthesis of epidemiological, environmental, and intermediate host genetic data. PLoS Negl Trop Dis 7(7):e2327

Schriewer A, Miller WA, Byrne BA, Miller MA, Oates S, Conrad PA, Hardin D, Yang HH, Chouicha N, Melli A, Jessup D, Dominik C, Wuertz S (2010) Presence of bacteroidales as a predictor of pathogens in surface waters of the Central California coast. Appl Environ Microbiol 76(17):5802-5814

Scott TW, Takken W, Knols BGJ, Boete C (2002) The ecology of genetically modified mosquitoes. Science 298(5591):117-119

Simons GW, Hilscher R, Ferguson HF, Gage SDM (1922) Report of the committee of bathing places. Am J Public Health 12(1):121-123

Sinton LW, Finlay RK, Lynch PA (1999) Sunlight inactivation of fecal bacteriophages and bacteria in sewage-polluted seawater. Appl Environ Microb 65(8):3605-3613

Smith RJ, Twedt RM, Flanigan LK (1973) Relationships of indicator and pathogenic bacteria in stream waters. Journal (Water Pollution Control Federation) 45(8):1736-1745

Smith EM, Gerba CP, Melnick JL (1978) Role of sediment in the persistence of enteroviruses in the estuarine environment. Appl Environ Microb 35(4):685-689

Smith RA, Alexander RB, Wolman MG (1987) Water-quality trends in the Nation's rivers. Science 235(4796):1607-1615

Smith J, Edwards J, Hilger H, Steck RTR (2008) Sediment can be a reservoir for coliform bacteria released into streams. J Gen Appl Microbiol 54:173-179

Snow J (1854) A Map of Cholera Deaths in London, 1840's. York University

Solo-Gabriele HM, Wolfert MA, Desmarais TR, Palmer CJ (2000) Sources of Escherichia coli in a coastal subtropical environment. Appl Environ Microb 66(1):230-237

Staley ZR, Rohr JR, Senkbeil JK, Harwood VJ (2014) Agrochemicals indirectly increase survival of E.coli O157:H7 and indicator bacteria by reducing ecosystem services. Ecol Appl, http://dx.doi.org/10.1890/13-1242.1

Steinmann P, Keiser J, Bos R, Tanner M, Utzinger J (2006) Schistosomiasis and water resources development: systematic review, meta-analysis, and estimates of people at risk. Lancet Infect Dis 6(7):411-425

Terzieva SI, McFeters GA (1991) Survival and injury of E. coli, Campylobacter jejuni, and Yersinia Enterocolitica in stream water. Can J Microbiol 37(10):785-790

U.S. Environmental Protection Agency (2010a) WATERS (Watershed Assessment, Tracking \& Environmental Results). Washington, DC, http://water.epa.gov/ scitech/datait/tools/waters/index.cfm. Accessed May 82014
U.S. Environmental Protection Agency (U.S. EPA) (1986) Ambient Water Quality Criteria for Bacteria. EPA 44015-84-002. Office of Regulations and Stand, Washington, DC, Accessed May 82014

U.S. Environmental Protection Agency (U.S. EPA) (2001) Protocol for Developing Pathogen TMDLs. National Summary of Impaired Waters and TMDL Information Washington, DC., Accessed May 82014

U.S. Environmental Protection Agency (U.S. EPA) (2010b) Protocol for Developing Pathogen TMDLs. National Summary of Impaired Waters and TMDL Information. Washington, DC, http://iaspub.epa.gov/waters10/ attains_nation_cy.control?p_report_type=T. Accessed May 82014

U.S. Environmental Protection Agency (U.S. EPA) (2012a) Impaired Waters and Total Maximum Daily Loads., Accessed May 82014

U.S. Environmental Protection Agency (U.S. EPA) (2012b) Drinking Water Contaminants. National Primary Drinking Water Regulations., http://water.epa. gov/drink/contaminants/\#one. Accessed May 182014

U.S. Environmental Protection Agency (U.S. EPA) (2014a) Protocol for Developing Pathogen TMDLs. National Summary of Impaired Waters and TMDL Information. Washington, DC, http://iaspub.epa.gov/waters10/ attains_nation_cy.control?p_report_type=T. Accessed May 82014

U.S. Environmental Protection Agency (U.S. EPA) (2014b) Cyanobacterial Harmful Algal Blooms., http://www2.epa.gov/nutrient-policy-data/cyanobacterialharmful-algal-blooms-cyanohabs. Accessed May 82014

U.S. Environmental Protection Agency (U.S. EPA) (2014c) Hypoxia., http://water.epa. gov/type/watersheds/named/msbasin/hypoxia101.cfm. Accessed May 82014

U.S. Geological Survey (U.S.G. S.) (2012) Dead Zone: the Source of the Gulf of Mexico's Hypoxia., http://www.usgs.gov/blogs/features/usgs_top_story/deadzone-the-source-of-the-gulf-of-mexicos-hypoxia/. Accessed Apr 282014

U.S. Geological Survey (U.S.G. S.) (2014) The Gulf of Mexico Hypoxic Zone., http://toxics.usgs.gov/hypoxia/hypoxic_zone.html. Accessed May 82014

Unc A, Goss MJ (2004) Transport of bacteria from manure and protection of water resources. Appl Soil Ecol 25:1-18

United Nation Children's Fund (UNICEF) (2014) World Water Day 2025: 4,000 children die each day from a lack of safe water., http://www.unicef.org/wash/ index_25637.html

Vareli K, Briasoulis E, Pilidis G, Sainis I (2009) Molecular confirmation of Planktothrix rubescens as the cause of intense, microcystin-synthesizing cyanobacterial bloom in Lake Ziros, Greece. Harmful Algae 8:447-453

Viau EJ, Goodwin KD, Yamahara KM, Layton BA, Sassoubre LM, Burns SL, Tong HI, Wong SHC, LU Y, Boehm AB (2011) Bacterial pathogens in Hawaiian coastal streams - associations with fecal indicators, land cover, and water quality. Water Res 45:3279-3290

Wade TJ, Calderon RL, Sams E, Beach M, Brenner KP, Williams AH, Dufour AP (2006) Rapidly measured indicators of recreational water quality are predictive of swimming-associated gastrointestinal illness. Environ Health Perspect 114:24-28

Wang Y, Bradford SA, Simunek J (2014a) Estimation and upscaling of dualpermeability model parameters for the transport of Ecoli D21g in soils with preferential flow. J Contam Hydrol 159:57-66

Wang Y, Bradford SA, Simunek J (2014b) Physicochemical factors influencing the preferential transport of Escherichia coli in soils. Vadose Zone J 13(1) doi:10.2136/vzj2013.07.0120

Wcislo R, Chrost RJ (2000) Survival of Escherichia coli in freshwater. Pol J Environ Stud 9(3):215-222

Weiskel PK, Howes BL, Heufelder GR (1996) Coliform contamination of a coastal embayment: Sources and transport pathways. Environ Sci Technol 30(6):1872-1881

White DL, Bushek D, Porter DE, Edwards D (1998) Geographic information systems (GIS) and kriging: analysis of the spatial and temporal distributions of the oyster pathogen Perkinsus marinus in a developed and an undeveloped estuary. J Shellfish Res 17(5):1473-1476

WHO (2011) Millennium Development Goals: progress towards the health-related Millennium Development Goals., http://www.who.int/mediacentre/factsheets/ fs290/en/index.html. Accessed 25 June 2012

Wilkes G, Brassard J, Edge TA, Gannon V, Jokinen CC, Jones TH, Lapen DR (2014) Coherence among different microbial source tracking markers in a small agricultural stream with or without livestock exclusion practices. Appl Environ Microbiol 79(20):6207-6219

Woolhouse MEJ (2002) Population biology of emerging and re-emerging pathogens. Trends Microbiol 10(10):s3-s7

World Bank (2010) Water Resource Management., Washington, D. C, http://www worldbank.org/en/topic/waterresourcesmanagement. Accessed 26 Apr 2012 
World Health Organization (WHO) (2010) Water Sanitation and Health., http:// www.who.int/water_sanitation_health/diseases/en/. Accessed 20 Apr 2012 World Health Organization (WHO) (2014) Water Quality and Health. Drinking water chlorination - A review of disinfection practices and issues., http:// www.waterandhealth.org/drinkingwater/wp.html. Accessed 28 Apr 2014

Yoshizawa S, Matsushima R, Watanabe MF, Harada K, Ichihara A, Carmichael WW, Fujiki $H$ (1990) Inhibition of protein phosphatases by microcystis and nodularin associated with hepatotoxicity. J Cancer Res Clin Oncol

$$
\text { 116:609-614 }
$$

doi:10.1186/s13568-014-0051-x

Cite this article as: Pandey et al:: Contamination of water resources by pathogenic bacteria. AMB Express 2014 4:51

\section{Submit your manuscript to a SpringerOpen ${ }^{\circ}$ journal and benefit from:}

- Convenient online submission

- Rigorous peer review

- Immediate publication on acceptance

- Open access: articles freely available online

- High visibility within the field

- Retaining the copyright to your article 